\title{
The Developmental Increase in ACh Current Densities on Rat Sympathetic Neurons Correlates with Changes in Nicotinic ACh Receptor $\alpha$-Subunit Gene Expression and Occurs Independent of Innervation
}

\author{
A. Mandelzys, ${ }^{1}$ B. Pié, ${ }^{1}$ E. S. Deneris, ${ }^{2}$ and E. Cooper ${ }^{1}$ \\ 1Department of Physiology, McGill University, Montréal, Québec, Canada H3G 1 Y6 and 2Department of Neuroscience, \\ Case Western Reserve University, Cleveland, Ohio 44106
}

\begin{abstract}
Determining factors that control the expression of neurotransmitter receptors and the mechanisms by which these factors operate is essential to understand how synapses form during development and how receptor numbers change in the adult. In this study, we have investigated one such factor, the influence of innervation, on the developmental expression of nicotinic $\mathrm{ACh}$ receptors (nAChRs) on neonatal rat sympathetic neurons, both in terms of ACh current densities, and in terms of mRNA levels for the transcripts that encode these receptors. To date, nine genes have been cloned that encode neuronal nAChRs subunits in mammals. We demonstrate that mRNA encoding five NAChR subunits, $\alpha 3, \alpha 5, \alpha 7, \beta 2$, and $\beta 4$, are present in neonatal rat sympathetic neurons. We show that mRNA levels for $\alpha 3$ and $\alpha 7$ subunits increase by more than threefold over the first 2 postnatal weeks, a period when most synapses are forming on the neurons; however, we observed no significant change in mRNA levels for $\alpha 5, \beta 2$, or $\beta 4$. Using whole-cell voltage-clamp techniques, we show that the increase in $\alpha$-subunit mRNA correlates with increases in ACh current densities, which double over the same period. To investigate the role of innervation, we cut the preganglionic nerve at birth and measured subunit mRNA levels and ACh current densities in denervated neurons 1-2 weeks later. Our results indicate that the preganglionic nerve differentially affects the mRNA level for the five nAChR transcripts, yet it has little influence on the developmental increase in ACh current densities.

[Key words: nicotinic receptors, neuronal ACh receptors, ligand-gated ion channels, sympathetic neurons, gene expression, RNase protection]
\end{abstract}

Studies on the neuromuscular junction have elucidated many molecular details involved in forming chemical synapses, and have generated some governing principles for synaptogenesis. These studies have shown that as synapses form, several com-

\footnotetext{
Received June 24, 1993; revised Sept. 28, 1993; accepted Oct. 14, 1993.

We thank Dr. J. Orlowski for his advice on the RNase protection assays, Drs. J. Boulter and P. Seguela for the $\alpha 7$ probe, and Dr. M. W. Cohen and P. De Koninck for comments on the manuscript. This work was supported by the MRC of Canada (E.C.), and the American Heart Association (91014080) and NIH (NS29123) (E.S.D.). E.C. is a chercheur boursier of the FRS du Québec.

Correspondence should be addressed to Dr. E. Cooper, Department of Physiology, McIntyre Medical Sciences Building, McGill University, 3655 Drummond Street, Montréal, Québec, Canada H3G 1 Y6.
}

Copyright (C) 1994 Society for Neuroscience $0270-6474 / 94 / 142357-08 \$ 05.00 / 0$ plex processes coordinate the expression of various proteins both in the presynaptic motor nerve terminals and in the postsynaptic muscle membranes (IIall and Sanes, 1993). Presumably, most of these processes also occur when synapses form between neurons; however, much less is known about the development of neuron-neuron synapses, and consequently it has not been fully resolved which of the principles that govern synaptogenesis on muscle also hold true for synapse formation on neurons. Given the dissimilarities between neurons and muscle as postsynaptic targets, one might expect that some discrepancies exist.

To learn more, we have investigated one aspect of synapse formation on neurons: the influence of the presynaptic nerve on mRNA levels for neurotransmitter receptor subunits during early postnatal development, and associated changes in the functional expression of these receptors. In mammalian muscle, embryonic myoblasts initially express all four nicotinic $\mathrm{ACh}$ receptor (nAChR) subunits, $\alpha, \beta, \gamma$, and $\delta$, shortly after fusion (reviewed by Hall and Sanes, 1993). However, in the carly postnatal pcriod, as the motor nerve terminals are establishing synaptic contact with muscle, the nuclei near the site of contact increase mRNA production for $\alpha, \beta$, and $\delta$ subunits, and they initiate expression of the $\epsilon$ subunit de novo; as $\epsilon$ mRNA increases, $\gamma$ mRNA production declines (Witzemann et al., 1989; Brenner et al., 1990; Martinou and Merlie, 1991). Nuclei away from the synapse continue to produce mRNA for $\alpha, \beta, \gamma$, and $\delta$, but at much lower levels than those near the synapse (Witzemann et al., 1989; Brenner et al., 1990). This changing pattern of expression for nAChR subunits in muscle, together with other factors, leads to a high density of $\alpha_{2} \beta \epsilon \delta$ receptors at the synapse, and a low density of $\alpha_{2} \beta \gamma \delta$ receptors elsewhere on the muscle membrane (Mishina et al., 1986; Gu and Hall, 1988).

In this article, we ask whether neurons undergo similar changes in expression of mRNA for neurotransmitter receptor subunits during early postnatal development as synapses form, and if so, what role do the presynaptic terminals have in this process. For our experiments, we have focused on the expression of nAChRs on neonatal rat sympathetic neurons, a preparation that has served as a model to investigate many aspects of synapse formation among neurons (Purves and Lichtman, 1985). In fact, most of what is known about the developmental expression of neuronal nAChRs has come from studies on autonomic ganglia (Schuetze and Role, 1987; Berg et al., 1989; Sargent, 1993). One advantage of this preparation, in addition to its easy accessibility, is that in the rat, most of the synapses on sympathetic 
neurons form over the first few postnatal weeks: the number of synapses at birth is only about $10 \%$ of that on sympathetic neurons in adult rats, and this number increases to about $90 \%$ over the next 3 weeks (Smolen and Raismen, 1980; Schafer et al., 1983; Rubin, 1985); this has allowed us to investigate changes in postnatal neurons over a period when a large number of synapses are being formed.

\section{Materials and Methods}

RNase protection assay. Total cellular RNA was isolated from superior cervical ganglia (SCG) dissected from postnatal day 1 (P1), P7, and P14 rats (CD strain, Charles River Canada), and from P7 and P14 rats in which the preganglionic nerve to the $S C G$ on one side had been cut. The RNA was extracted from the ganglia with a guanidinium isothiocyanate-phenol-chloroform extraction procedure described by Chomczynski and Sacchi (1987). In some experiments, in order to isolate RNA from relatively pure neuronal and non-neuronal cell populations from the ganglia, the ganglia were enzymatically dissociated (Mandelzys and Cooper, 1992) and the resultant cell suspension was centrifuged through a 35\% Percoll (Pharmacia) gradient that separates the cell suspension into a neuronal fraction and non-neuronal cell fraction; this was routinely confirmed by culturing aliquots from each fraction. Total cellular RNA was then isolated from each fraction separately as above. Typically, the non-neuronal cells contribute less than $10 \%$ of the total cellular RNA from P1-P14 ganglia. After dissociation, we recover approximately $70-80 \%$ of the RNA of the intact ganglia, which is roughly the same proportion of viable neurons after this procedure. This suggests that by dissociating the ganglia we are not causing a preferential loss of non-neuronal cells, thereby under estimating their contribution. In some control expcriments, total cellular RNA was isolated from the brains of $P 1$ animals using the same procedure as above.

The RNase protection assays were according to that described by Krieg and Melton (1987). Briefly, ${ }^{32} \mathrm{P}$-radiolabeled antisense RNA probes to $\alpha 2, \alpha 3, \alpha 4, \alpha 5, \alpha 7, \beta 2, \beta 3$, and $\beta 4 \mathrm{nAChR}$ subunits were synthesized using an in vitro transcription method. Linearized plasmids, pGEM, or pSP64, containing subcloned portions of the cDNA for each neuronal nAChR subunit, were transcribed using a bacteriophage SP6, T3, or T7 RNA polymerase. The following region of each cDNA was used: $\alpha 2$ [HYP16(9); Wada et al., 1988], bases 1737-1932, protected length 195 nucleotides; $\alpha 3$ (pPCA48E4; Boulter et al., 1986), bases 1557-1815, protected length 258 nucleotides; $\alpha 4$ [p3ZHYA23(2)B2; Rogers et al., 1992], bases $0-553$, protected length 553 nucleotides; $\alpha 5$ (AAlpha 5; Boulter et al., 1990), bases 1160-1639, protected length 479 nucleotides; $\alpha 7$ [PHIP306(s)], bases $0-476$, protected length 476 nuclcotides; $\beta 2$ (pGPR49; Deneris et al., 1988), bases 1617-2195, protected length 578 nucleotides; $\beta 3$ (pESD7; Deneris et al., 1989), bases 568-1021, protected length 453 nucleotides; $\beta 4$ (pZPC13; Duvoison et al., 1989), bases 2049 2460 , protected length 411 nucleotides. The thermal stabilites for all probes, as calculated from their melting temperatures, differed by less than $1{ }^{\circ} \mathrm{C}$. Each probe was gel purified before use. For each reaction, 2$10 \mu \mathrm{g}$ of total cellular RNA was combined with $100,000-200,000 \mathrm{cpm}$ of radiolabeled probe and allowed to hybridize overnight at $60^{\circ} \mathrm{C}$. The remaining single-stranded RNAs were digested with RNase $T 1$ and the protected RNA:RNA duplexes were denatured and run on a $5 \%$ polyacrylamide- $8 \mathrm{M}$ urea gel. The gels were exposed to film (Kodac XAR) at $-70^{\circ} \mathrm{C}$ for $15-24 \mathrm{hr}$. In addition, the protected bands were quantified with a phosphor imaging system (Fujix BAS 2000, Bio Image Analyzer), or, in early experiments, by densitometry. The specific activity of each riboprobe was calculated from the number of adenine bases. To quantify relative levels of mRNA among different transcripts, the relative intensities of the hybridization signals were divided by the specific activity of the corresponding riboprobe. As a control, we performed RNase protection assays with two different $\alpha 7$ riboprobes that protected nonoverlapping regions of $\alpha 7 \mathrm{mRNA}$, and also differed in length. The ratio of the hybridization signal for the two probes was in close agreement with that predicted from the specific activity of each probe. In experiments to quantify changes in mRNA over the first 2 postnatal weeks, RNA for P1, P7, and P14 were always run on the same gel, as was the case for changes between control and denervated neurons.

Preganglionic denervation. The surgical procedures used to cut the preganglionic nerve to the SCG in Pl rats was similar to that described by Voyvodic (1987) and to that which we have used previously (McFarlane and Cooper, 1992). First, P1 rat pups were anesthetized by cooling, and then the right sympathetic trunk was exposed and ligated midway between the ganglion and the first rib; the nerve was cut rostral to the ligature and the caudal stump displaced ventrally to impede reinnervation of the ganglion. In control experiments, we recorded from the postganglionic nerve while stimulating the preganglionic stump to confirm that we had removed the preganglionic inputs to the SCG. In addition, when the eyes opened at P12, the denervated animals had pronounced ptosis of the right eye. For all experiments involving RNase protection assays with total cellular RNA from denervated ganglia, tota cellular RNA from the left SCGs with the preganglionic nerve intact served as the control. In these animals, the total cellular RNA from denervated ganglia was usually $90-100 \%$ of that in control ganglia.

Electrophysiology. ACh current densities were measured with wholecell patch-clamp techniques (Hamill et al., 1981). Acutely dissociated sympathetic neurons from $S C G$ dissected from $P 1$ or $P 14$ rats, in culture from 18 to $30 \mathrm{hr}$, were voltage clamped at $-50 \mathrm{mV}$ while $50 \mu \mathrm{M} \mathrm{ACh}$ dissolved in perfusion media (see below) was applied to cell body by pressure ejection from a puffer pipette positioned $20-30 \mu \mathrm{m}$ from the soma; the pipettes had tip diameters of 15-20 $\mu \mathrm{m}$ (Mandelzys and Cooper, 1992). The recordings were done with a LIST EPC-7 amplifier at room temperature $\left(22-23^{\circ} \mathrm{C}\right)$, and the data were filtered at $3 \mathrm{kHz}$ digitized at $44 \mathrm{kHz}$ by a pulse code modulating unit (PCM 701, Sony), and stored on a Beta VCR (Sony). The patch electrodes had resistances of 2-6 M , and the current was balanced to zero in the perfusion solution. All currents were normalized to cell capacitance by integrating the capacity current evoked by a $5 \mathrm{mV}$ hyperpolarizing voltage step from a holding potential of $-50 \mathrm{mV}$. The recording chamber was continually perfused at a rate of $1 \mathrm{ml} / \mathrm{min}$ with a solution consisting of 140 $\mathrm{mM} \mathrm{NaCl}, 5.4 \mathrm{~mm} \mathrm{KCl}, 2.8 \mathrm{mM} \mathrm{CaCl}_{2}, 0.18 \mathrm{~mm} \mathrm{MgCl}_{2}, 10 \mathrm{~mm} \mathrm{N-2-}$ hydroxyethylpiperazine- $N$ '-2-ethanesulfonic acid (HEPES), $5.6 \mathrm{mM}$ glucose, and was adjusted to $\mathrm{pH} 7.4$ with $\mathrm{NaOH}$. The solution in the recording pipette was $80 \mathrm{~mm} \mathrm{KF}, 60 \mathrm{~mm} \mathrm{~K}$-acetate, $5 \mathrm{~mm} \mathrm{NaCl}, 1 \mathrm{~mm}$ $\mathrm{MgCl}_{2}, 10 \mathrm{~mm}$ ethylene glycol-bis( $\beta$-aminoethyl ether $)-N, N, N^{\prime}, N^{\prime}$-tetraacetic acid (EGTA), and $10 \mathrm{~mm}$ HEPES and was adjusted to $\mathrm{pH} 7.2$ with $\mathrm{KOH}$.

Standard $t$ tests were done to assess the significance of differences between values obtained from denervated and control neurons, and between neurons of different ages.

\section{Results}

To date, nine genes have been cloned that encode neuronal nAChRs subunits in mammals (Deneris et al., 1991; Role, 1992; Sargent, 1993): six $\alpha$ subunits $(\alpha 2-\alpha 7)$, whose designation is based on a pair of vicinal cysteines at positions equivalent to 192 and 193 of the muscle $\alpha$ subunit, a location believed to be near the ACh binding site (Kao et al., 1984); and three $\beta$ subunits $(\beta 2-\beta 4)$, which lack these paired cysteines. Like muscle nAChRs, neuronal nAChRs are likely to be pentameric structures containing two $\alpha$ subunits and three $\beta$ subunits (Anand et al., 1991; Cooper et al., 1991).

We used RNase protection assays to determine which neuronal $\mathrm{nAChR}$ transcripts are present in neonatal sympathetic neurons. As shown in Figure $1 A$, mRNA encoding five of the subunits are expressed in sympathetic neurons from Pl rats: $\alpha 3$, $\alpha 5, \alpha 7, \beta 2$, and $\beta 4$. We quantified the hybridization signals with a phosphor imaging system, taking into account the specific activity of each riboprobe. These data indicate that the ratios of $\alpha 3$ mRNA levels in P1 neurons relative to the other four subunits are approximately as follows: $\alpha 5: \alpha 3,1: 5 ; \alpha 7: \alpha 3,1: 2$; $\beta 2: \alpha 3,1: 2 ;$ and $\beta 4: \alpha 3,3: 2$. We did not detect mRNA for $\alpha 2$ or $\alpha 4$, nor did we detect mRNA for $\beta 3$. To ensure that $\alpha 2, \alpha 4$, and $\beta 3$ probes were capable of protecting the appropriate transcripts, we performed RNase protection assays on P1 rat brain RNA; our results indicate that all eight transcripts are present in neonatal brain (data not shown).

As we used whole ganglia in these experiments, it is conceivable that some transcripts might be expressed in the ganglionic non-neuronal cells. To demonstrate that the transcripts are spe- 
A

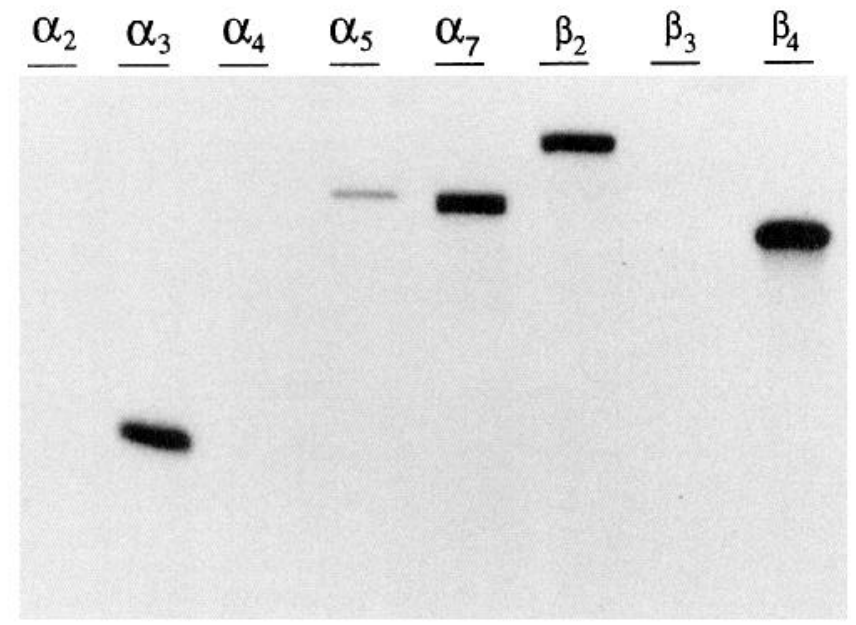

B

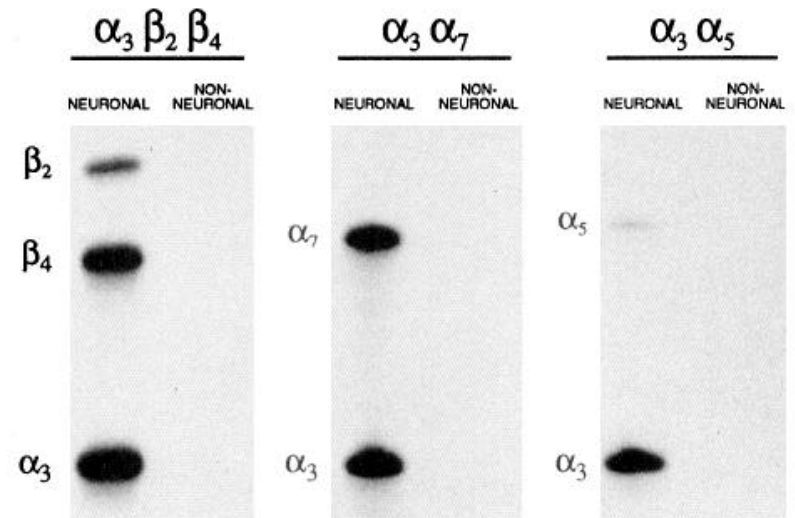

Figure 1. nAChR subunit mRNAs expressed in rat SCG ganglia. $A$, Total cellular RNA was isolated from P1 rat SCG ganglia and $5 \mu \mathrm{g}$ was used in each RNase protection assay; a single radiolabeled probe was used for each reaction. $B, \mathrm{P} 7 \mathrm{SCG}$ were dissociated and the neurons and non-neuronal cells were separated by density centrifugation; $5 \mu \mathrm{g}$ of total cellular RNA, isolated from the two populations, was used in each RNase protection assay. This figure represents three different assays and shows that only the neuronal populations had detectable transcripts. The non-neuronal cell lanes also demonstrate that all probes were completely digested by RNase T1. The autoradiograms in $A$ and $B$ were exposed for $20 \mathrm{hr}$.

cifically localized to the neurons, we separated the neuronal and non-neuronal cell populations by density gradient centrifugation and assayed RNA isolated from both cell types separately. Over $90 \%$ of total cellular RNA from the ganglia was present in the neuronal fraction, a value that changes little over the first 2 postnatal weeks. Figure $1 B$ shows that no transcripts were detected in RNA from P7 ganglionic non-neuronal cells, indicating that the $\mathrm{nAChR}$ subunit mRNAs in whole ganglia, such as shown in Figure $1 A$, are in the neurons. Similar results were also obtained with non-neuronal cells from $\mathrm{P} 1$ and $\mathrm{P} 14$ ganglia. In addition, preliminary in situ hybridization experiments indicate that individual neurons express all five $\mathrm{nAChR}$ transcripts ( $\mathrm{P}$. De Koninck and E. Cooper, unpublished observations).

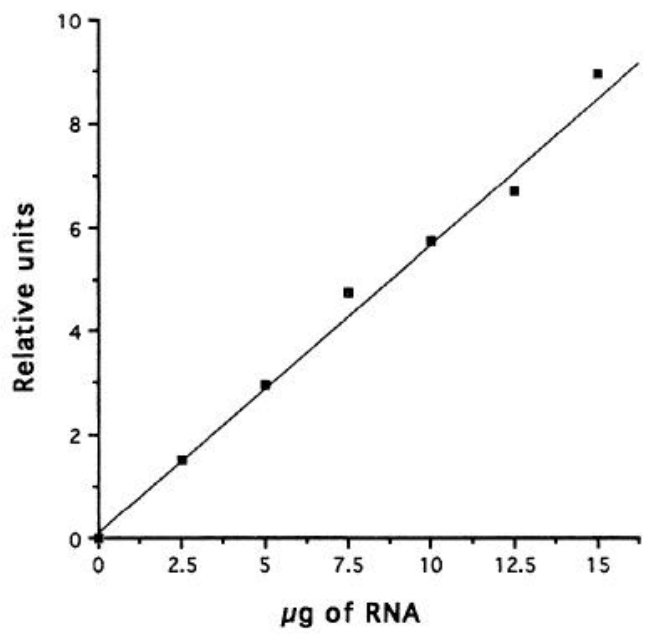

Figure 2. This figure shows the relative intensities of the hybridization signals from RNase protection assays for $\alpha 7$ mRNA with increasing concentrations of RNA from SCG neurons. The hybridization signals were quantified with a phosphor imaging analyzer and are linear up to at least $15 \mu \mathrm{g}$ of total cellular RNA. Similar results were obtained for $\alpha 3, \alpha 5, \beta 2$, and $\beta 4$.

\section{Increase $n A C h R$ subunit $m R N A$ s with development}

In the rat SCG, the number of synapses immediately after birth is less than $10 \%$ of that in the adult (Smolen and Raisman, 1980; Rubin, 1985). During the following 2-3 postnatal weeks, the number of synapses increase severalfold as the sympathetic neurons develop more extensive dendritic arbors (Smolen and Raisman, 1980; Schafer et al., 1983). Consequently, we asked whether $\mathrm{nAChR}$ mRNA levels reflect this developmental increase in cholinergic synapse formation. To quantify the changes in mRNA, we measured the hybridization signals with a phosphor imaging analyzer, and Figure 2 shows that the intensity of the hybridization signal increases linearly with increasing concentrations of RNA, thereby allowing us to make comparisons of signals over a similar range of intensities. Figure 3 shows an autoradiogram from a typical experiment in which we assayed SCG RNA from P1, P7, and P14 animals. Hybridization signals like those shown in Figure 3 were quantified from seven such experiments. Figure 4 shows the changes in mRNA levels over the first 2 postnatal weeks relative to the level at $\mathrm{P} 1$ for all five nAChR transcripts. The largest change occurs in $\alpha 3$ mRNA: it increases 3.6-fold over the 2 week period. $\alpha 7$ mRNA levels show the next largest change, increasing almost threefold, with most of the increase occurring during the first week. On the other hand, mRNA for $\alpha 5, \beta 2$, and $\beta 4$ transcripts showed little change over the 2 week period. $\alpha 5$ mRNA levels appeared to increase 1.5 -fold on average, but the increase was not statistically significant. As a result of the developmental changes in mRNA levels, at P14, the ratios of $\alpha 3 \mathrm{mRNA}$ levels relative to the other four subunits are approximately as follows: $\alpha 5: \alpha 3,1: 12 ; \alpha 7: \alpha 3$, $2: 5 ; \beta 2: \alpha 3,1: 7 ;$ and $\beta 4: \alpha 3,2: 5$. As is the case in P1 ganglia, mRNA for $\alpha 2, \alpha 4$, or $\beta 3$ was not detected in ganglia from P7 or P14 animals (data not shown).

\section{Innervation differentially controls $m R N A$ levels}

It is well known that cutting motor nerves to skeletal muscle results in a large increase in extrajunctional $\mathrm{nAChRs}$ within a few days, a process referred to as "denervation supersensitivity" (Axelsson and Thesleff, 1959; Fambrough, 1979), and this in- 


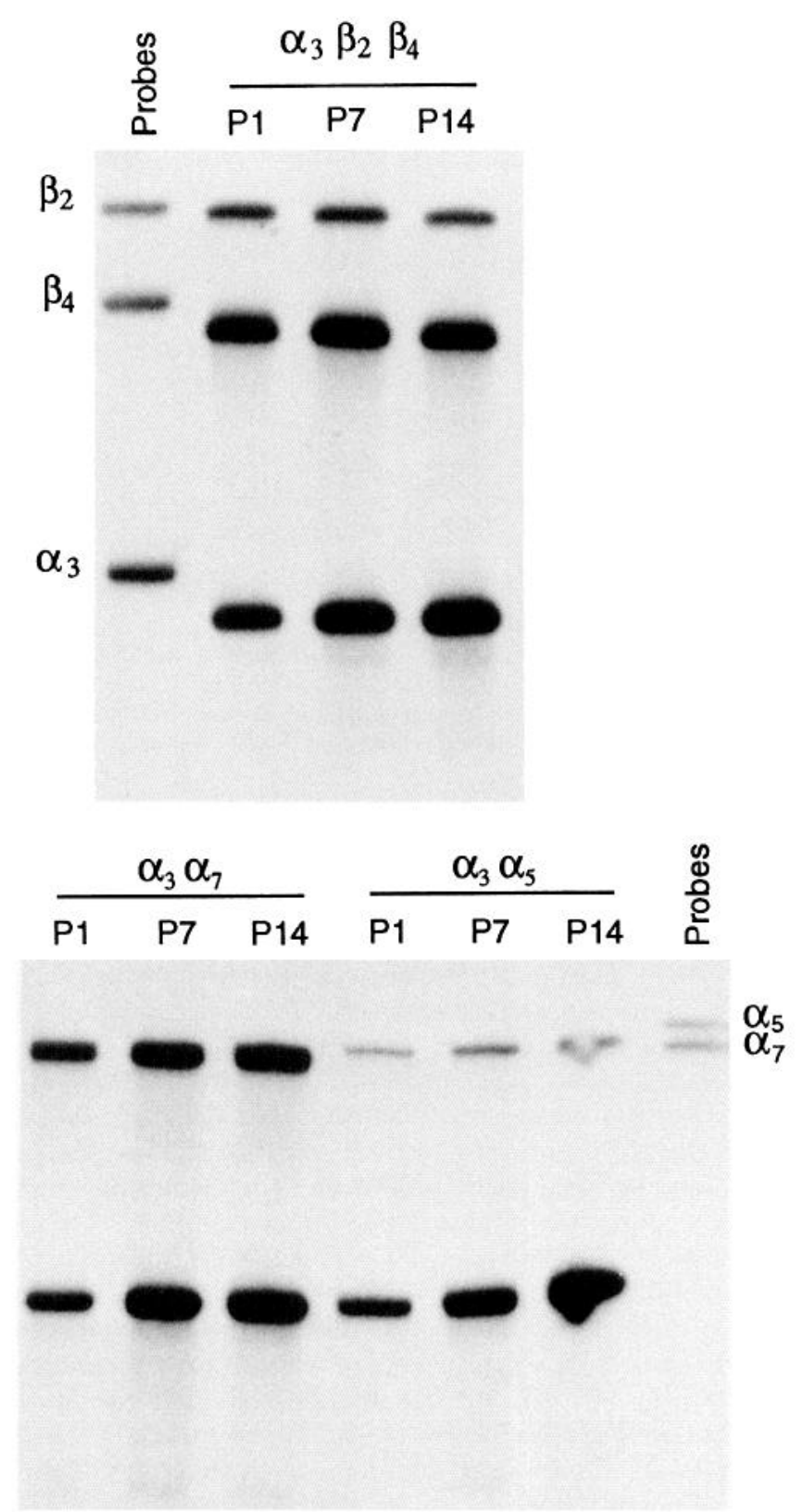

Figure 3. Postnatal development of nAChR transcripts. Total cellular RNA was isolated from P1, P7, and P14 SCG ganglia and $5 \mu \mathrm{g}$ was used in each RNase protection assay. The upper autoradiogram shows the protected transcripts for $\alpha 3, \beta 2$, and $\beta 4$ combined, and the lower autoradiograms show the protected transcripts for both $\alpha 7$ and $\alpha 3$, as well as $\alpha 5$ and $\alpha 3$ combined. The probe lanes consist of $600 \mathrm{cpm}$ of undigested probes. Both autoradiograms were exposed for $20 \mathrm{hr}$.

crease in functional nAChRs corresponds to a severalfold elevation in mRNA for the receptor subunits (Goldman et al., 1988; Brenner et al., 1990; Merlie et al., 1984). To determine whether similar changes occur in rat sympathetic neurons after denervation, we cut the preganglionic nerve to the SCG in P1 animals, and measured mRNA levels for $\mathrm{nAChR}$ transcripts from denervated sympathetic neurons 1 and 2 weeks later. Figure 5 shows data from one such experiment. The results from this and five other denervation experiments were measured relative to the contralateral controls as shown in Figure 6. We observed no significant difference between neurons denervated for 1 week versus those denervated for 2 weeks, and consequently, Figure 6 includes data from both groups. Figure 6 indicates that the mRNA levels for all five transcripts in denervated neurons were less than that in control innervated neurons; however, the amount of change was different for the five. We observed the largest decrease in $\alpha 7$ mRNA levels; it was only $64 \%$ of that in control neurons. These data indicate that much of the developmental increase for $\alpha 7$ mRNA levels depends on preganglionic innervation. Similarly, $\alpha 5 \mathrm{mRNA}$ levels were only $68 \%$ of controls. On the other hand, $\alpha 3$ mRNA levels, which increase almost fourfold from P1 to P14, were $81 \%$ of control indicating that most of the developmental increase in $\alpha 3$ mRNA levels is nerve independent. $\beta$ subunit mRNA levels changed the least after denervation; $\beta 4$ mRNA levels were $87 \%$ of control, and $\beta 2$ mRNA levels were $89 \%$ of control. As in control innervated neurons, we failed to detect mRNA for $\alpha 2, \alpha 4$, or $\beta 3$ in denervated neurons (data not shown) demonstrating that the preganglionic nerves do not suppress the expression of these transcripts during postnatal development.

\section{Increases in ACh current densities correlate with increases in $\alpha$-subunit mRNA levels}

We used whole-cell voltage-clamp techniques to measure $\mathrm{ACh}$ current densities on SCG neurons during postnatal development and after denervation in order to correlate the appearance of functional $\mathrm{nAChRs}$ with the changes that we observed in mRNA levels for the different $\mathrm{nAChR}$ subunits. Figure 7 shows that the ACh current densities on neonatal rat SCG neurons increase nearly twofold from P1 to P14; this increase is a result of a fourfold increase in ACh current and a twofold increase in wholecell capacitance. However, preganglionic innervation is not responsible for the postnatal increase in ACh current densities on these neurons; ACh current densities on neurons denervated for 2 weeks are not significantly different from those of control innervated neurons (see Fig. 7). These results indicate that the developmental increase in ACh current density is due to factors other than innervation.

\section{Discussion}

In this article, we demonstrate that mRNA levels for $\alpha 3$ and $\alpha 7$ subunits increase significantly over the first 2 postnatal weeks, and this increase correlates with an increase in ACh current densities. Our results also indicate that the preganglionic nerve differentially affects mRNA levels for the five $\mathrm{nAChR}$ transcripts expressed by neonatal rat sympathetic neurons, yet it has little influence on the ACh current densities.

We show that five $\mathrm{nAChR}$ transcripts are present in $\mathrm{Pl}$ rat sympathetic neurons, $\alpha 3, \alpha 5, \alpha 7, \beta 2$, and $\beta 4$; the mRNA levels for $\alpha 3$ are approximately twofold greater than $\alpha 7$ and $\beta 2$, fivefold greater than $\alpha 5$, but only $50 \%$ of that for $\beta 4$. These transcripts have also been shown to be expressed in chick autonomic neurons (Boyd et al., 1988; Couturier et al., 1990a; Listerud et al., 1991; Vernallis et al., 1993), and recently their amounts have been quantified in embryonic chick ciliary neurons (Corriveau and Berg, 1993). We did not detect mRNA for $\alpha 2, \alpha 4$, or $\beta 3$, although mRNA for $\alpha 4$ is present in embryonic chick sympathetic neurons (Listerud et al., 1991). A significant finding of our study is that during early postnatal development in the rat, there is a differential increase in mRNA levels for the various $\mathrm{nAChR}$ subunits present in sympathetic neurons. The greatest change occurs in $\alpha 3$ mRNA levels, which increase nearly fourfold over the first 2 postnatal weeks. In addition, mRNA levels 

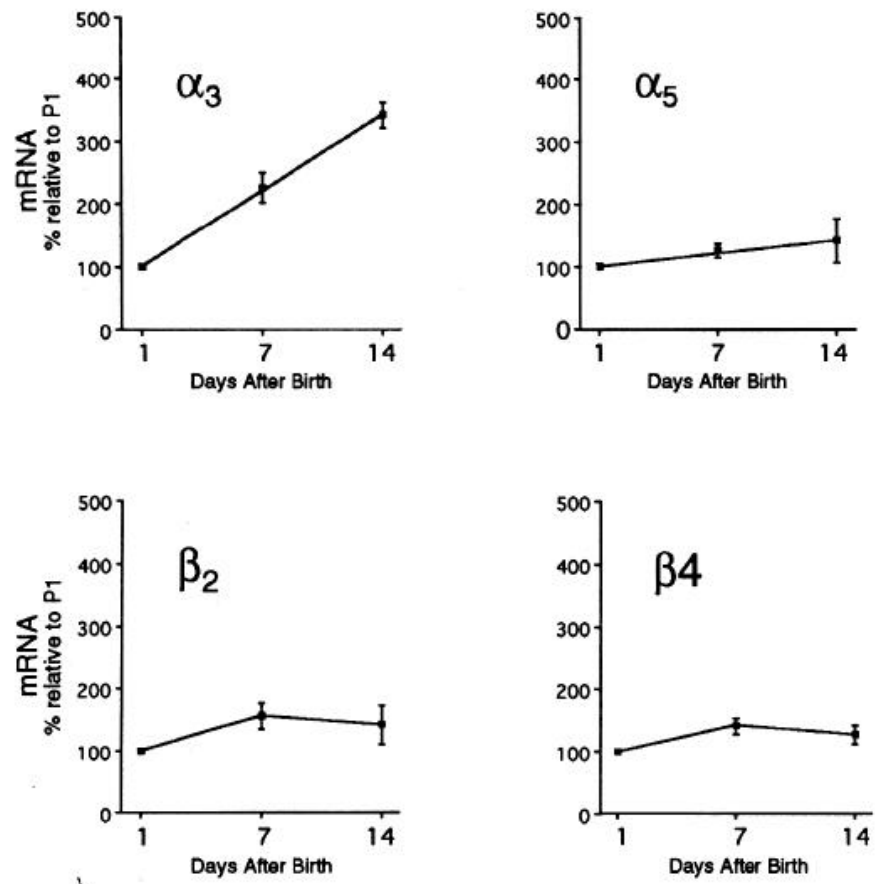

for $\alpha 7$ increase threefold over the same period. On the other hand, there is little or no change in mRNA levels for $\alpha 5, \beta 2$, or $\beta 4$. As a result of these changes, at P14, $\alpha 3$ mRNA is approximately 2.5 -fold greater than $\alpha 7$ and $\beta 4,7$-fold greater than $\beta 2$, and almost 12-fold greater than $\alpha 5$.

Our findings that during postnatal development mRNA levels for $\alpha 3, \alpha 5$, and $\beta 4$ increase differently are interesting because the three genes are clustered in the rat (Boulter et al., 1990) and chick (Couturier et al., 1990a) genome. In this cluster, $\beta 4$ is
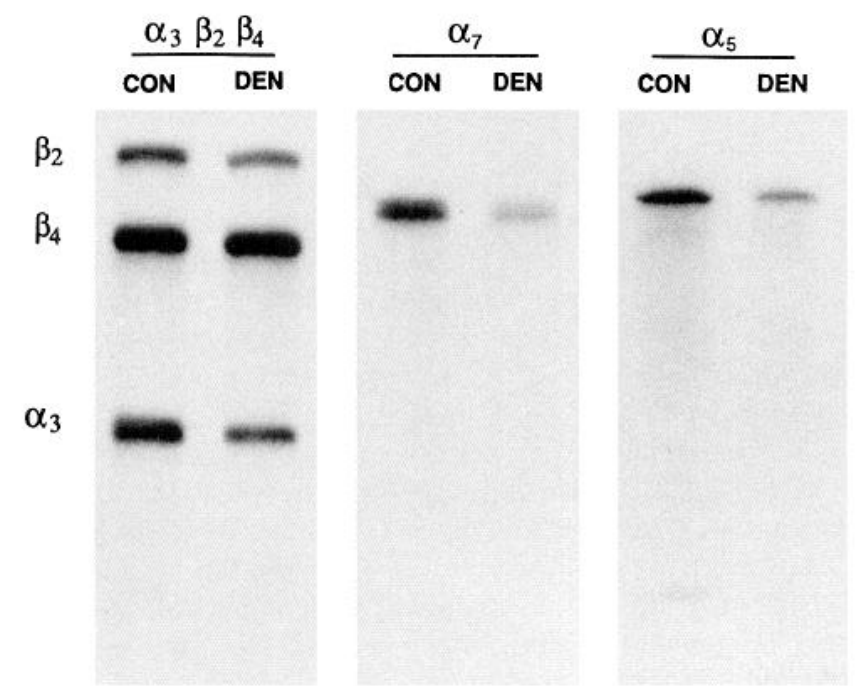

Figure 5. Differential regulation of nAChR transcripts following denervation. Total cellular RNA was isolated from both P14 innervated and P14 denervated SCG ganglia from the contralateral side and $5 \mu \mathrm{g}$ was used in each RNase protection assay. This figure shows three different autoradiograms; each autoradiogram compares protected $\mathrm{nAChR}$ transcripts from denervated SCG ganglia $(D E N)$ with those from control innervated SCG ganglia $(C O N)$. The autoradiograms were exposed for $13 \mathrm{hr}$ for the combination of $\alpha 3, \beta 2$, and $\beta 4$; for $20 \mathrm{hr}$ for $\alpha 7$, and for $120 \mathrm{hr}$ for $\alpha 5$.

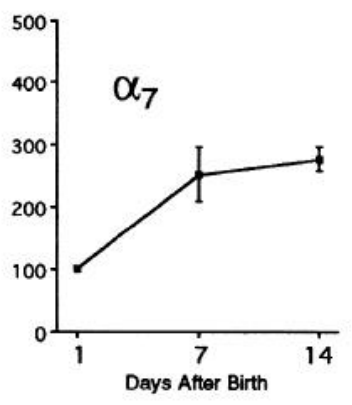

Figure 4. Developmental regulation of nAChRs subunit mRNA levels. This figure shows the change in mRNA, determined with RNase protection assays, for the five $\mathrm{nAChR}$ transcripts present in SCG neurons measured over the first 2 weeks of postnatal development. For each transcript, the values at $\mathrm{P} 7$ and $\mathrm{P} 14$ are relative to the values at P1. Each point represents the mean of 7-10 experiments, and the error bars represent the SEM. upstream from $\alpha 3$, and $\alpha 5$ is further downstream and is transcribed in the opposite direction. Our results suggest that the regulation of mRNA levels encoding these three subunits is different, although we have not distinguished between regulatory mechanisms affecting transcription, RNA processing, or mRNA stability.

The changes in $\alpha 3$ and $\alpha 7$ mRNA levels correlate with changes in ACh current densities. We show that there is a twofold increase in ACh current densities over the first 2 postnatal weeks, a period when most synapses form on these neurons (Smolen and Raisman, 1980; Rubin, 1985). In addition, we show that denervation on P1 has little effect on the developmental increase in ACh current densities. We find that ACh current densities on denervated P14 neurons are not different from those on control neurons of the same age. The lack of effect of denervation

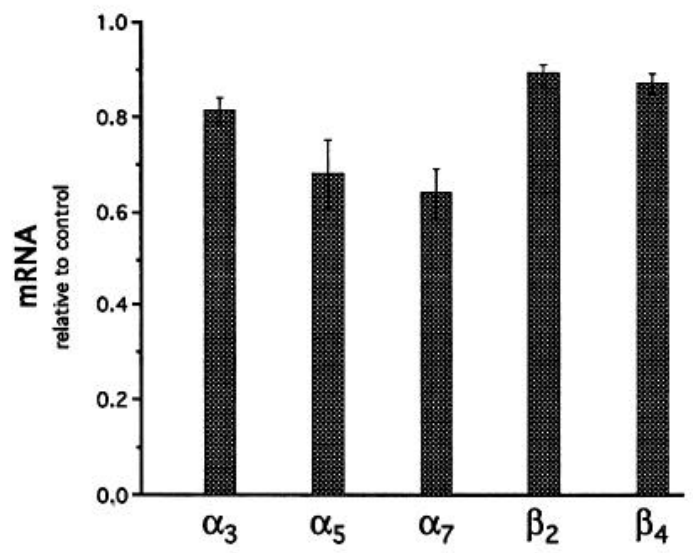

Figure 6. Relative changes in mRNA levels for $\mathrm{nAChR}$ subunits after denervation. This figure shows the change in mRNA levels for all five nAChR transcripts after 1-2 weeks of denervation, as measured with RNase protection assays and quantified with a phosphor image analyzer. The values are relative to the levels in contralateral control neurons, and represent the mean of six experiments; the error bars are the SEM. 


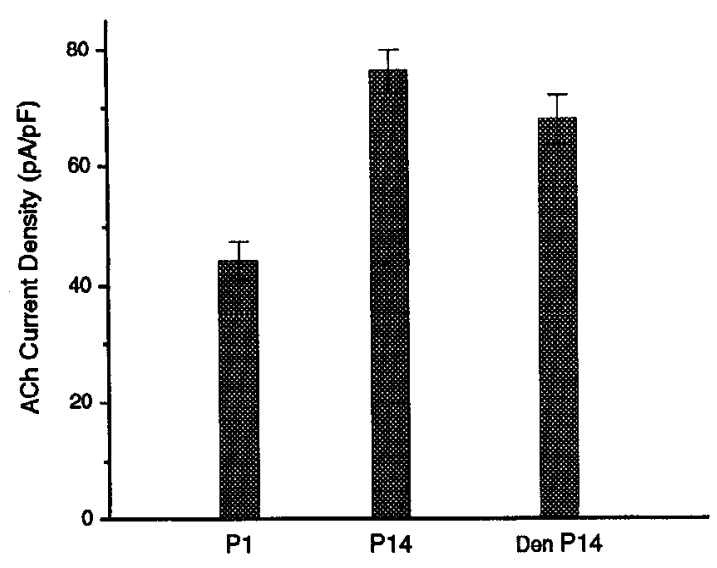

Figure 7. ACh current densities. This figure shows the mean $\mathrm{ACh}$ current densities for acutely dissociated P1 $(n=32), \mathrm{P} 14(n=28)$, and P14 neurons denervated for 2 weeks $(n=30)$. ACh current densities increase during postnatal development independent of the presence of preganglionic innervation. Error bars represent SEM.

on current densities correlates with the small effect that denervation has on $\alpha 3, \beta 2$, and $\beta 4$ mRNA levels, but not for $\alpha 5$ or $\alpha 7$, and, in fact, the absolute levels for all five transcripts are relatively abundant in denervated neurons. As these neurons had been already contacted by nerves before denervation, it is conceivable that the initial expression of $\mathrm{nAChR}$ genes in sympathetic neurons is induced by innervation, but thereafter, much of the cxpression is independent of innervation.

Our finding that the ACh current densities double during the period when most of the synapses are forming is consistent with previous studies on embryonic chick autonomic neurons (Margiotta and Gurantz, 1989; Engisch and Fischbach, 1990). Furthermore, denervation of chick autonomic neurons does not affect ACh currents (McEachern et al., 1989; Engisch and Fischbach, 1992). In contrast to the $19 \%$ decrease in $\alpha 3 \mathrm{mRNA}$ levels in rat sympathetic neurons, $\alpha 3$ mRNA levels in chick ciliary neurons drop by $63 \%$ after denervation (Boyd et al., 1988); this correlates with a drop in the intracellular pool for $n A C h R s$, but without altering the number of nAChRs at the surface (Jacob and Berg, 1988). The lack of effect of denervation on surface receptors is consistent with our results on ACh current densities.

Our results that $\beta 2$ mRNA levels in rat sympathetic neurons change very little over the period of synapse formation and is largely unaffected by denervation at birth appear somewhat contrary to data on changes in $\beta 2$ mRNA in the developing chick optic tectum. In the chick optic tectum, mRNA levels for $\beta 2$ increase 10-fold during embryonic development, over the time when the retinal axons make synaptic contact in the tectum, and this increase in $\beta 2 \mathrm{mKNA}$ is prevented if the eye is removed at embryonic day 2 (Matter et al., 1990). One possibility for this discrepancy is that $\beta 2$ is regulated differently in different types of neurons. However, as mentioned above, in the rat SCG, the preganglionic axons had already innervated the sympathetic neurons at birth; conceivably, this initial contact could have induced the expression of $\beta 2$, and by birth, $\beta 2$ expression loses its dependence on innervation.

Our results on mRNA encoding $\alpha 7$ and $\alpha 5$ need further discussion. We showed that the levels of $\alpha 7 \mathrm{mRNA}$ increase threefold during postnatal development, and of the five transcripts present in rat sympathetic neurons, the $\alpha 7$ mRNA levels are most affected by denervation at P1. It has been demonstrated that $\alpha 7$ mRNA encodes a subunit of the $\alpha$-bungarotoxin $(\alpha-$ BTX) binding protein (Couturier et al., 1990b; Schoepfer et al., 1990; Seguela et al., 1993), yet the role for these proteins on neurons is not clear. Consistent with our results on $\alpha 7$ mRNA, it has been shown that $\alpha$-BTX binding on chick autonomic neurons increases during development (Greene, 1976), and decreases after denervation (Jacob and Berg, 1987). However, $\alpha$-BTX does not block ACh-gated inward current on autonomic neurons (Brown and Fumagalli, 1977; reviewed by Chiappinelli, 1985), nor does it appear to be localized at the synaptic sites (Jacob and Berg, 1983; Loring et al., 1985), and in fact, recent evidence from chick ciliary neurons indicates that $\alpha 7$ and $\alpha 3$ are not part of the samc receptor protein (Vernallis et al., 1993; but see Listerud et al., 1991). Furthermore, when $\alpha 7$ mRNA is expressed in frog oocytes, $\alpha 7$ proteins form a homomeric ligandgated ion channel that is activated by $\mathrm{ACh}$ and nicotine and blocked by $\alpha$-BTX, and has a high permeability to calcium (Couturier et al., 1990b; Seguela et al., 1993). In addition, recent evidence suggests that when the $\alpha$-BTX binding proteins on chick ciliary neurons are activated by low agonist concentrations, as may occur during synapse formation, there is an increase in intracellular calcium concentrations (Vijayaraghavan et al., 1992). Perhaps during synapse formation the $\alpha 7$-containing proteins increase intracellular calcium, which subsequently regulates second messengers that modulate other proteins needed to establish the synapse (see Changeux, 1991).

The role for $\alpha 5$ is less certain. There is evidence that $\alpha 5$ codes for a sequence that binds $\alpha$-BTX (McLane et al., 1990), and therefore may be part of a $\alpha$-BTX binding protein on these neurons. To date, there is no evidence that mRNA for $\alpha 5$, either alone or in combination with other nAChR transcripts, can direct the synthesis of functional nAChRs when expressed in frog oocytes (Boulter et al., 1990; Couturier et al., 1990a). On the other hand, there is recent evidence that in chick ciliary neurons some nAChRs contain both $\alpha 3$ and $\alpha 5$ in the same receptor complex (Vernallis et al., 1993). We show that in sympathetic neurons from $\mathrm{P} 1$ rats, $\alpha 5 \mathrm{mRNA}$ levels are approximately fivefold less than those for $\alpha 3$, and over the next 2 weeks, as the ACh current densities increase almost twofold, the ratio of $\alpha 5$ to $\alpha 3$ mRNA decreases almost threefold resulting in a $\alpha 5$ : $\alpha 3$ ratio of roughly $1: 12$. It is likely that there are only two $\alpha$ subunits in nAChRs (Anand et al., 1991; Cooper et al., 1991); if differences in mRNA levels reflect similar differences in protein levels, then our data on relative mRNA levels for $\alpha 3$ and $\alpha 5$ suggest that only a small proportion of the receptors would incorporate both $\alpha 3$ and $\alpha 5$. However, further experiments are needed to establish if this is indeed the case.

It is interesting to compare our results on postnatal changes in mRNA levels for neuronal nAChR subunits in sympathetic neurons with changes that occur for $\mathrm{nAChR}$ in developing mammalian skeletal muscle. The initial expression of $\mathrm{nAChR}$ genes that occurs in muscle shortly after fusion is part of an endogenous myogenic program that activates all five muscle $\mathrm{nAChR}$ genes: $\alpha, \beta, \gamma$, and $\delta$ genes are activated at high levels, and the $\epsilon$ gene at low levels (Piette et al., 1990; Martinou and Merlie, 1991; Jia et al., 1992; Prody and Merlie, 1992). Shortly after birth, a reciprocal change in $\gamma$ and $\epsilon$ mRNA levels occurs, such that by the second postnatal week, $\epsilon \mathrm{mRNA}$ increases roughly 10-fold whereas $\gamma$-mRNA levels drop to barely detectable levels (Mishina et al., 1986; Witzemann et al., 1989; Martinou and Merlie, 1991). Innervation does not appear to be responsible for the postnatal increase in $\epsilon$ mRNA, but it is responsible for 
the decrease in $\gamma$ mRNA levels: for example, denervation at birth in the rat, and at P4 in the mouse, does not prevent the increase in $\epsilon$ mRNA, but it does promote a large increase in $\gamma$ mRNA; in addition, muscles denervated in adults of both species continue to express $\epsilon$ mRNA (Witzemann et al., 1989; Brenner et al., 1990; Martinou and Mcrlic, 1991). This indicates that whereas the initial increase in $\epsilon$ mRNA levels may depend on the motor nerve terminals; thereafter, $\epsilon$ mRNA levels are independent of innervation. In rat sympathetic neurons, we did not observe a switch in the expression of the five neuronal nAChR subunit genes, and only mRNA for $\alpha 3$ and $\alpha 7$ showed a significant increase during the first 2 postnatal weeks. It would not be surprising if, like muscle, the initial expression of $\mathrm{AChR}$ subunit genes is due to an intrinsic program that occurs in developing neuroblasts as they become committed to a particular neuronal phenotype. This would not necessarily exclude an influence from the ingrowing preganglionic terminals embryonically, but by birth, our results indicate that the expression of all five subunit genes is largely independent of innervation; this is similar to the $\epsilon$ gene in muscle. Strict comparison between the regulation of $\mathrm{nAChR}$ subunit genes in sympathetic neurons and muscle is difficult, in part, because skeletal muscles are multinucleated cells, and the control of $\mathrm{nAChR}$ gene expression in the extrasynaptic nuclei is different from the control in the synaptic nuclei. For example, the $\epsilon$ gene is selectively expressed by synaptic nuclei (Merlie and Sanes, 1985; Brenner et al., 1990), and in addition, the regulation of $\mathrm{nAChR}$ genes by the extrasynaptic nuclei, which express the $\gamma$ gene, is controlled by innervation and activity (reviewed by Hall and Sanes, 1993). As such, it appears that the regulation of neuronal $n A C h R$ genes by rat sympathetic neurons during postnatal development resembles more closely the regulation of muscle $\mathrm{nAChR}$ genes by synaptic nuclei compared to regulation that occurs by extrasynaptic nuclei.

Lastly, we found no evidence for denervation supersensitivity, which has been shown to occur after denervation of many other targets, notably muscle. The lack of an increase in ACh current densities on denervated rat sympathetic neurons is consistent with recent findings on amphibian autonomic neurons (Dunn and Marshall, 1985; Streichert and Sargent, 1992). Similar to the lack of effect on ACh current density, denervation of sympathetic neurons at birth has little effect on either the growth of dendrites (Voyvodic, 1987), or on the developmental switch in voltage-gated $\mathrm{K}$ currents that occurs postnatally (McFarlane and Cooper, 1992). It may be that other factors regulate mRNA levels for $\mathrm{AAChR}$ subunits in these neurons, in particular, factors emanating from the targets. A likely target factor could be NGF, which has been shown to increase $\mathrm{ACh}$ current densities on rat nodose neurons in culture (Mandelzys and Cooper, 1992).

\section{References}

Anand R, Conroy WG, Schoepfer R, Whiting P, Lindstrom J (1991) Neuronal nicotinic acetylcholine receptors expressed in Xenopus oocytes have a pentameric quarternary structure. J Biol Chem 266: 11192-11198.

Axelsson J, ThesleffS (1959) A study of super-sensitivity in denervated mammalian skeletal muscle. J Physiol (I ond) 147:178-193.

Berg DK, Boyd RT, Halvorsen SW, Higgins LS, Jacob MH, Margiotta JF (1989) Regulating the number and function of neuronal acetylcholine receptors. Trends Neurosci 12:16-21.

Boulter J, Evans K, Goldman D, Martin G, Treco D, Heinemann S, Patrick J (1986) Isolation of a cDNA clone coding for a possible neuronal nicotinic acetylcholine receptor $\alpha$-subunit. Nature 319:368374.
Boulter J, O'Shea-Greenfield A, Duvoisin RM, Connolly JG, Wada E, Jensen A, Gardner PD, Ballivet M, Deneris ES, McKinnon D, Heinemann S, Patrick J (1990) $\alpha 3, \alpha 5$, and $\beta 4$ : three members of the rat neuronal nicotinic acetylcholine receptor-related gene family form a gene cluster. J Biol Chem 265:4472-4482.

Boyd RT, Jacob MH, Couturier S, Ballivet M, Berg DK (1988) Expression and regulation of neuronal acetylcholine receptor mRNA in chick ciliary ganglia. Neuron 1:495-502.

Brenner H, Witzemann V, Sakmann B (1990) Imprinting of acetylcholine receptor messenger RNA accumulation in mammalian neuromuscular synapses. Nature 344:544-547.

Brown DA, Fumagalli L (1977) Dissociation of $\alpha$-bungarotoxin binding and receptor block in the rat superior cervical ganglion. Brain Res 129:165-168.

Changeux JP (1991) Compartmentalized transcription of acetylcholine receptor genes during motor endplate epigenesis. New Biol 3:413429.

Chiappinelli VA (1985) Actions of snake venom toxins on neuronal nicotinic receptors and other neuronal receptors. Pharmacol Ther 31 : $1-32$.

Chomczynski P, Sacchi N (1987) Single-step method of RNA isolation by acid guanidinium thiocyanate-phenol-chloroform extraction. Anal Biochem 162:156-159.

Cooper E, Couturicr S, Ballivet M (1991) Pentameric structure and subunit stoichiometry of a neuronal acetylcholine receptor. Nature 350:235-238.

Corriveau RA, Berg DK (1993) Coexpression of multiple acetylcholine receptor genes in neurons: quantification of transcripts during development. J Neurosci 13:2662-2671

Couturier S, Erkman L, Valera S, Rungger D, Bertrand S, Boulter J, Ballivet M, Bertrand D (1990a) $\alpha 5, \alpha 3$, and non- $\alpha 3$ : three clustered avian genes encoding neuronal nicotinic acetylcholine receptor-related subunits. J Biol Chem 265:17560-17567.

Couturier S, Bertrand D, Matter J-M, Hernandez M-C, Bertrand S, Millar N, Valera S, Barkas T, Ballivet M (1990b) A neuronal nicotinic acetylcholine receptor subunit $(\alpha 7)$ is developmentally regulated and forms a homo-oligomeric channel blocked by $\alpha$-Btx. Neuron 5:847-856

Deneris ES, Connolly J, Boulter J, Wada E, Wada K, Swanson LW, Patrick J, Heinemann S (1988) Primary structure and expression of $\beta 2$ : a novel subunit of neuronal nicotinic acetylcholine receptors. Neuron 1:45-54.

Deneris ES, Boulter J, Swanson LW, Patrick J, Heinemann S (1989) B3: a new member of nicotinic acetylcholine receptor gene family is expressed in brain. J Biol Chem 264:6268-6372.

Deneris ES, Connolly J, Rogers SW, Duvoisin R (1991) Pharmacological and functional diversity of neuronal nicotinic acetylcholine receptors. Trends Pharmacol Sci 12:34-40.

Dunn PM, Marshall I.M (1985) I ack of nicotinic supersensitivity in frog sympathetic neurones following denervation. J Physiol (Lond) 363:211-225.

Duvoisin RM, Dencris ES, Patrick J, Heincmann S (1989) The functional diversity of the neuronal nicotinic acetylcholine receptors is increased by a novel subunit: $\beta 4$. Neuron 3:487-496.

Engisch KL, Fischbach GD (1990) The development of ACh- and GABA-activated currents in normal and target-deprived embryonic chick ciliary ganglia. Dev Biol 139:417-426.

Engisch KL, Fischbach GD (1992) The development of ACh- and GABA-activated currents in embryonic chick ciliary ganglion neurons in the absence of innervation in vivo. J Neurosci 12:1115-1125.

Fambrough DM (1979) Control of acetylcholine receptors in skeletal muscle. Physiol Rev 59:165-227.

Goldman D, Brenner HR, Heinemann S (1988) Acetylcholine receptor $\alpha-, \beta-, \Gamma-$, and $\delta$-subunit mRNA levels are regulated by muscle activity. Neuron 1:329-333.

Greene LA (1976) Binding of $\alpha$-bgt to chick sympathetic ganglia; properties of the receptor and its rate of appearance during development. Brain Res 111:135-145.

Gu Y, Hall ZW (1988) Immunological evidence for a change in subunits of the acetylcholine receptor in developing and denervated rat muscle. Neuron 1:117-125.

Hall ZW, Sanes JR (1993) Synaptic structure and development: the neuromuscular junction. Cell 72/Neuron 10[Suppl]:99-121.

Hamill OP, Marty A, Neher E, Sakmann B, Sigworth FJ (1981) Improved patch clamp techniques for high resolution current recording 
from cells and cell-free membrane patches. Pfluegers Arch 391:85100 .

Jacob MH, Berg DK (1983) The ultrastructural localization of $\alpha$-bungarotoxin binding sites in relation to synapses on chick ciliary ganglion neurons. J Neurosci 3:260-271.

Jacob MH, Berg DK (1987) Effects of preganglionic denervation and postganglionic axotomy on acetylcholine receptors in the chick ciliary ganglion. J Cell Biol 105:1847-1854.

Jacob MH, Berg DK (1988) The distribution of acetylcholine receptors in chick ciliary ganglion neurons following disruption of ganglionic connections. J Neurosci 8:3838-3849.

Jia HK, Tsay HJ, Schmidt J (1992) Analysis of binding and activating functions of the chick muscle acetylcholine receptor $\gamma$ subunit upstream sequence. Cell Mol Neurobiol 12:241-258.

Kao P, Dwork AJ, Kaldany RR J, Silver ML, Wideman J, Stein S, Karlin A (1984) Identification of the $\alpha$-subunit half-cysteine specifically labelled by an affinity reagent for the acetylcholine receptor binding site. J Biol Chem 259:1 1662-11665.

Krieg PA, Melton DA (1987) In vitro RNA synthesis with SP6 polymerase. Methods Enzymol 155:397-415.

Listerud M, Brussard AB, Devay P, Colman DR, Role I.W (1991) Functional contribution of neuronal AChR subunits by antisense oligonucleotides. Science 254:1518-1521.

Loring RH, Dahm LM, Zigmond RE (1985) Localization of $\alpha$-bungarotoxin binding sites in the ciliary ganglion of the embryonic chick: an autoradiographic study at the light and electron microscopic level. Neuroscience 14:645-660.

Mandelzys A, Cooper E (1992) Effects of ganglionic satellite cells and NGF on the expression of nicotinic acetylcholine currents by rat sensory neurons. J Neurophysiol 67:1213-1221.

Margiotta JF, Gurantz D (1989) Changes in the number, function, and regulation of nicotinic acetylcholine receptors during neuronal development. Dev Biol 135:326-339.

Martinou J-C, Merlie JP (1991) Nerve-dependent modulation of acetylcholine $\epsilon$-subunit gene expression. J Neurosci 11:1291-1299.

Matter J-M, Matter-Sadzinski L, Ballivet M (1990) Expression of neuronal nicotinic acetylcholine receptor genes in the developing visual system. EMBO J 9:1021-1026.

McEachern AE, Jacob MH, Berg DK (1989) Differential effects of nerve transection on the ACh and GABA receptors of chick ciliary ganglion neurons. J Neurosci 9:3899-3907.

McFarlane S, Cooper E (1992) Postnatal development of voltage-gated K currents on rat sympathetic neurons. J Neurophysiol 67:12911300 .

McLane KE, Wu X, Conti-Tronconi BM (1990) Identification of a brain acetylcholine receptor $\alpha$ subunit able to bind $\alpha$-bungarotoxin. J Biol Chem 265:9816-9824.

Merlie JP, Sanes JR (1985) Concentration of acetylcholine receptor mRNA in synaptic regions of adult muscle. Nature 317:66-69.

Merlie JP, Isenberg KE, Russell D, Sanes JR (1984) Denervation supersensitivity in skeletal muscle: analysis with a cloned cDNA probe. J Cell Biol 99:332-335.

Mishina M, Takai T, Imoto K, Noda M, Takahashi T, Numa S, Methfessel C, Sakmann B (1986) Molecular distinction between fetal and adult forms of muscle acetylcholine receptor. Nature 321:406-411.

Piette J, Bessereau JL, Huchet M, Changeux JP (1990) Two adjacent
myoD-binding sites regulate expression of the acetylcholine receptor $\alpha$ subunit gene. Nature 345:353-355.

Prody CA, Merlie JP (1992) The 5 ' flanking region of the mouse muscle nicotinic acetylcholine receptor $\beta$ subunit gene promotes expression in cultured muscle cells and is activated by MRF4, myogenin and myoD. Nucleic Acids Res 20:2367-2372.

Purves D, Lichtman JW (1985) The principles of neural development Sunderland, MA: Sinauer.

Rogers SW, Mandelzys A, Deneris ES, Cooper E, Heinemann S (1992) The expression of nicotinic acetylcholine receptor subunit mRNA, protein and electrophysiology by $\mathrm{PC}_{12}$ cells treated with NGF. J Neurosci 12:4611-4623.

Role LW (1992) Diversity in primary structure and function of neuronal nicotinic acetylcholine receptor channels. Curr Opin Neurosci $2: 254-262$.

Rubin E (1985) Development of the rat superior cervical ganglion: initial stages of synapse formation. J Neurosci 5:697-704.

Sargent PB (1993) The diversity of neuronal nicotinic acetylcholine receptors. Annu Rev Neurosci 16:403-443.

Schafer T, Schwab ME, Thoenen H (1983) Increased formation of preganglionic synapses and axons due to a retrograde trans-synaptic action of nerve growth factor in the rat sympathetic nervous system. J Neurosci 3:1501-1510.

Schoepfer R, Conroy WG, Whiting P, Gore M, Lindstrom J (1990) Brain $\alpha$-bungarotoxin binding protein cDNAs and MAbs reveal subtypes of this branch of the ligand-gated ion channel gene superfamily. Neuron 5:35-48.

Schuetze SM, Role LW (1987) Developmental regulation of nicotinic acetylcholine receptors. Annu Rev Neurosci 10:403-457.

Seguela P, Wadiche J, Dineley-Miller K, Dani J, Patrick JW (1993) Molecular cloning, functional properties, and distribution of rat brain $\alpha 7$ nicotinic cation channel highly permeable to calcium. J Neurosci 13:596-604.

Smolen AJ, Raisman G (1980) Synapse formation in the rat superior cervical ganglion during normal development and after neonatal deafferentation. Brain Res 181:315-323.

Streichert L, Sargent PB (1992) The role of acetylcholinesterase in denervation supersensitivity in the frog cardiac ganglion. J Physiol (Lond) 445:249-260.

Vernallis AB, Conroy WG, Berg DK (1993) Neurons assemble acetylcholine receptors with as many as three kinds of subunits while maintaining subunit segregation among receptor subtypes. Neuron $10: 451-464$.

Vijayaraghavan S, Pugh PC, Zhang Z, Rathouz MM, Berg DK (1992) Nicotinic receptors that bind $\alpha$-bungarotoxin on neurons raise intracellular free calcium. Neuron 8:353-362.

Voyvodic JT (1987) Development and regulation of dendrites in the rat superior cervical ganglion. J Neurosci 7:904-912.

Wada K, Ballivet M, Boulter J, Connolly J, Wada E, Deneris ES, Swanson LW, Heinemann S, Patrick J (1988) Functional expression of a new pharmacological subtype of brain nicotinic acetylcholine receptor. Science 240:330-334.

Witzemann V, Barg B, Criado M, Stein E, Sakmann B (1989) Developmental regulation of five subunit specific mRNAs encoding acetylcholine receptor subtypes in rat muscle. FEBS Lett 242:419-424. 